\title{
Aiming for a Cool School Library Activities in Japanese School Libraries connected with the Community, University, Other Schools and the World
}

\author{
Yoko TAKAJI, Yuki MAEDA \\ Toshimagaoka Joshi Gakuen Junior \& Senior High School, \\ Shibuya Junior \& Senior High School \\ Tokyo \\ Japan \\ y-takaji@toshimagaoka.ed.jp \\ maeda@shibuya-shibuya-jh.ed.jp
}

\begin{abstract}
Our students are tremendously connected with others through the internet. However, direct communication is decreasing nowadays. We would like to introduce four activities with human warmth done by students at two private middle schools in Japan. They are 1. Reading Aloud to Children at Toshima City Library (Toshimagaoka) to contribute to local community, 2. Philosophy Café (Toshimagaoka) with a neighbor University, 3. Bibliobattle, Japanese new reading activity with other schools (Toshimagaoka \& Shibuya) and 4. Used Book Fair (Shibuya) to donate the UNESCO Fund.
\end{abstract}

Keywords: Book reading volunteering, Philosophy Café, Bibliobattle, Used Book Fair, Library Committee

\section{Four Encouraged Activities for Students}

\section{Reading Aloud to Children at Toshima City Library}

Toshimagaoka volunteer students read aloud to 3-5 year-old children and their parents for 30 minutes on Saturday afternoons 6 times a year. In addition, they often tell children a story in a form of illustrated cards, and use hand gestures while reading aloud. For the Japanese society with the trend towards the nuclear family, this activity gives a great opportunity for students to talk to people of different generations and interact with the local community. We would like to tell you about the interaction between different graders through this activity, and what students did for younger children to make them interested in books. 
Book reading volunteering was started in the academic year of 2005 by one student in charge of the library, who had a passion for introducing fascinating, profound picture books to students. After a discussion, it has been done for students inside the school (from 1st year junior high to 3rd year high school students) using 20 minutes out of their lunch breaks. For junior high and high school students, picture books with themes such as war and peace, refugee problems and environmental problems are chosen. This activity by students in charge of the library and volunteers were done by teachers in turns to gather more audience and has become popular. All management was handled by students in the next academic year and they had the opportunity to work with Toshima City Library after three years of work inside the school.

Since 2008, 4 out of all 10 members have started to take turns in book reading volunteering as "story telling by Toshimagaoka girls", 6 times per year (the third Saturday of odd-numbered months at 14:00-14:30) for children aged $3-6$. As a process, the student in charge choose a book beforehand and then discusses it with the library staff in charge about the size and content of the picture book (if it is easy to see from a distance or if it is not too long) to decide. Next, the captain lets the other members know about the book and the student in charge of drawing posters creates and places mini posters for display and to advertise the picture book to be read. The member in charge of reading has practiced on her own and also rehearses at the library before the real event. Everything, including the way to read, the way to hold the book and how to direct the gathering, has been handed down from experienced seniors to juniors.

These activities have connected students of different years inside the school, who usually do not have interactions, and it has a valuable opportunity for learning about nuclear families by creating opportunities to communicate with young children and their parents outside the school, who are also rare to interact with. In fact, a student who does not have chances to interact with young children has said that it was something new and fun, and something to do again. This activity, based in the local community, has turned 9 years old, counting 40 times. There are 32 current members. The first captain is currently working as part of a prosperous nursery staff team contributing to society.

\section{Philosophy Café with a local university}

We usually organize Tetsugaku (Philosophy) Café 3 times a year for all the students who are interested in this event. A volunteer professor from a local university is a facilitator and encourages students to discuss a topic for about two hours. Usually, 10-15 students join this event. The topic to be discussed is decided each time and students can freely discuss and share their opinions on topics such as "What is beauty?" "What is freedom?" and "About Voting at Age 18", which could be too serious to discuss between friends. We 
feel a growing need for students to express their ideas freely and also to have philosophical understanding of things in the global society. We would like to introduce school library-driven activities developed in the context of a library, which is a great source of intelligence.

It has started from an invitation from the City Library staff, who we have known from the book reading events that they wanted us to join their "Philosophy Cafe", planned for high school students. 5 high school students from the 1st year and 2nd year, joined as a result of promoting it through posters put up inside the school. 15 people in total, including students from other schools, working people, and college students came to the gathering held at the local community center. The themes were "Why are we happy when we are doing something we like?" and "Is lying always a bad thing?" They seemed to be stimulated greatly by "questions without answers", which are different from school classes, and they said that they were surprised to know how others think so differently from them.

Since then, this gathering has been held 3 times a year for around 3 years, until now by Professor Tetsuya Kawano from the Literature department of the local Rikkyo University, who was the facilitator. The location is our school library or inside Rikkyo University. Students gather freely based on the theme discussed in a circle for 2 hours (including breaks) during each event. Students are recruited beforehand through promotion of the event by putting up notices and such. On the actual day, the facilitator directs the discussion so that it does not fall apart. Contents of the discussions are as stated in the accompanying sheet.

Themes include familiar topics such as "What is individuality?", "What is girl power?" and social situations such as "regarding the voting age of 18". Each time, students broaden their views by "listening to others' opinions carefully" and "knowing other people's thoughts". They say that they can talk seriously about things they usually do not talk about and that they can talk freely and continue to think as there are no correct answers. As it ends without having answers, many students feel that they want more time and would like to come again. More and more are becoming regulars and bringing their friends as well. This activity currently reaching its 12 th time and during their 4 th year, is an optimum place to cultivate skills to "think, make decisions, and express" required in the "prospective students' academic rating exam (to be confirmed)"starting in 2021 in Japan. 
In addition, Professor Tetsuya Kawano has studied abroad in the US and France for one year to prepare for the "Philosophy Cafe" in 2014. He is planning to create a network of "Philosophy Cafes" on a global level.

\begin{tabular}{|c|c|c|c|c|c|c|c|c|}
\hline \multicolumn{9}{|c|}{ Philosophy Café } \\
\hline & Date & Time & \begin{tabular}{|ll} 
Junior & High \\
School & Student
\end{tabular} & \begin{tabular}{|c|} 
High \\
School \\
Student
\end{tabular} & Total & Topic Theme & Place & Facilitator \\
\hline & Dec.15,2012 & 2:00pm $\sim 4: 00 \mathrm{pm}$ & 0 & 5 & & $\begin{array}{l}\text { Why are we happy when we can do } \\
\text { what we want to do? }\end{array}$ & $\begin{array}{l}\text { Community } \\
\text { Center }\end{array}$ & $\begin{array}{l}\text { Dr.Tetuya Kono. } \\
\text { (Professor of Rikkyo } \\
\text { University) }\end{array}$ \\
\hline & & & & & & Is lying always a bad thing? & & \\
\hline & March.28,2013 & $10: 00 \mathrm{am} \sim 12: 00 \mathrm{pm}$ & 0 & 8 & & Is beauty truth or preference? & $\begin{array}{l}\text { Library of our } \\
\text { School }\end{array}$ & $\begin{array}{l}\text { Dr.Tetuya Kono. } \\
\text { (Professor of Rikkyo } \\
\text { University) }\end{array}$ \\
\hline & & & & & & $\begin{array}{l}\text { Does destiny exist or do we create our } \\
\text { lives? }\end{array}$ & & 3 Graduate students \\
\hline & July.16,2013 & $13: 00 \sim 15: 00$ & 0 & 16 & 16 & What is reality? & \begin{tabular}{|l|} 
Campus \\
(Rikkyo \\
University) \\
\end{tabular} & \begin{tabular}{|l|}
$\begin{array}{l}\text { Dr.Tetuya Kono. } \\
\text { (Professor of Rikkyo } \\
\text { University) }\end{array}$ \\
\end{tabular} \\
\hline & & & & & & $\begin{array}{l}\begin{array}{l}\text { Do you like seeing yourself in the } \\
\text { mirror? }\end{array} \\
\end{array}$ & & 3 Graduate students \\
\hline & & & & & & What is love? & & \\
\hline & Dec.17,2013 & $13: 00 \sim 15: 00$ & 7 & 3 & 10 & When do you feel happiness? & $\begin{array}{l}\text { Library of our } \\
\text { School }\end{array}$ & $\begin{array}{l}\text { Dr.Tetuya Kono. } \\
\text { (Professor of Rikkyo } \\
\text { University) }\end{array}$ \\
\hline & & & & & & Read a Picturebook"The Giving Tree" & & 2 Graduate students \\
\hline & March.18,2014 & 14:00 16:00 & 0 & 7 & & $\begin{array}{l}\text { Why do bad things happen to good } \\
\text { people? }\end{array}$ & \begin{tabular}{|l|} 
Campus \\
(Rikkyo \\
University) \\
\end{tabular} & \begin{tabular}{|l|} 
Dr.Tetuya Kono. \\
(Professor of Rikkyo \\
University)
\end{tabular} \\
\hline & July.14,2014 & 13:00 15:00 & 4 & 10 & 14 & What is individuality? & $\begin{array}{l}\text { Library of our } \\
\text { School }\end{array}$ & $\begin{array}{l}\text { Dr.Toshiro Terada. } \\
\text { (Professor of sophia } \\
\text { University) }\end{array}$ \\
\hline & & & & & & & & 2 Graduate students \\
\hline & Dec.22,2014 & $13: 00 \sim 15: 00$ & 6 & 9 & 15 & What is girl power? & \begin{tabular}{|l} 
Library of our \\
School
\end{tabular} & \begin{tabular}{|l|}
$\begin{array}{l}\text { Dr.Toshiro Terada. } \\
\text { (Professor of Jyoti } \\
\text { University) }\end{array}$ \\
\end{tabular} \\
\hline & & & & & & & & 2 Graduate students \\
\hline & March.19,2015 & $13: 00 \sim 15: 00$ & 5 & 3 & & $\begin{array}{l}\text { Let's talk about freedom! When you are } \\
\text { free and not free }\end{array}$ & \begin{tabular}{|l|} 
Library of our \\
School
\end{tabular} & \begin{tabular}{|l|} 
Dr.Toshiro Terada. \\
(Professor of sophia \\
University)
\end{tabular} \\
\hline & & & & & & & & $\begin{array}{l}\text { Tour: Shibuya Kyouikugak } \\
\text { uen Makuhari's } \\
\text { 2Teachers }\end{array}$ \\
\hline & July.10,2015 & 13:00 15:00 & 10 & 11 & 21 & The voting age of 18 & $\begin{array}{l}\text { Library of our } \\
\text { School }\end{array}$ & $\begin{array}{l}\text { Dr.Tetuya Kono. } \\
\text { (Professor of Rikkyo } \\
\text { University) }\end{array}$ \\
\hline 10 & Dec. 15,2015 & $13: 00 \sim 15: 00$ & 9 & 4 & 13 & Read a Picturebook"Why?" & $\begin{array}{l}\text { Library of our } \\
\text { School }\end{array}$ & \begin{tabular}{|l} 
Dr.Tetuya Kono. \\
(Professor of Rikkyo \\
University)
\end{tabular} \\
\hline 11 & March.15,2016 & $13: 30 \sim 15: 00$ & 8 & 1 & & Meeting and parting & $\begin{array}{l}\text { Library of our } \\
\text { School }\end{array}$ & $\begin{array}{l}\text { Dr.Tetuya Kono. } \\
\text { (Professor of Rikkyo }\end{array}$ \\
\hline & & & & & & & & 3 Graduate students \\
\hline
\end{tabular}

\section{Bibliobattle}

Bibliobattle is a book review battle thought up by Tadahiro Taniguchi, an associate professor of Ritsumeikan University. It is a game played in groups of 5 or 6 people, rapidly gaining popularity these days in which each participant introduces one's favorite book in 5 minutes followed by a few minutes' question-and-answer session and then votes for the book which attracted one's interest the most to decide the champion book. It is practiced during Japanese and English classes of junior high at Shibuya and networking events organized by the Library Committee are held with Toshimagaoka and other schools. The motto is "Know books through people, Know people through books." and the events are always enjoyable. 
In 2013, the first preliminary round inside the school was held to participate in "the 1st Book Review Battle Bibliobattle of high school students in the metropolitan area", sponsored by the Book Culture Promotion Council. The book introduced by a male student from Shibuya High School won at this tournament, which had representatives gathered from each participating school. This was covered extensively in the newspapers at that time.

While aiming to win at such events, a spirit to introduce books in a fun way was born at the library and Bibliobattle has been held every semester in Toshimagaoka. Making use of cultural festivals and reading weeks, it started with only Japanese books. A native teacher suggested doing a Bibliobattle of English books the following year, which started a project for students to talk freely about English books with native teachers, during the autumn reading week. Three years on, in addition to students' Japanese and English Bibliobattle, there is a "Teacher Bibliobattle", where teachers introduce books at lunch breaks. For books introduced by popular teachers, students rush in to listen even if it is a short time during lunch breaks. Bibliobattle has been mentioned in the Japanese textbook for the 3rd year junior high school students starting in 2016. It is also a nationwide activity promoting reading. How wonderful is it that you can strengthen your courage and knowledge by having fun and introducing books as if playing a game?

\section{Bibliobattle of English books}

Bibliobattle of English books was started during the reading week in autumn of 2014, following Bibliobattle activities of Japanese books which started in 2013. The five participants, including three students (a 1st year high school student, a 2nd year high school student and a 3rd year junior high school student) and two native teachers introduced English books at the first event. The 2-minute question-and-answer sessions were also done in English, and were done in a relaxed atmosphere with occasional laughs. The second time was held six months later, and also had total of five participants, including three students (a 1st year high school student and two 3rd year junior high school students) and two native teachers. The role of the presenter was left to the native teachers at this event. Skillful questions were added and this made the question-and-answer sessions livelier than the previous event. It seemed to be a good experience for the students as there are not many opportunities to make a speech in English. There were about 10 viewers who seemed to listen with admiration. "LIFE ON THE REFRIGERATOR DOOR" was chosen as the champion book.

At the third event during the reading week in autumn of 2016, there were four participants (two 1st year, one 2nd year, and one 3rd year junior high school student) and 25 viewers. All of them were junior high school students, which means that fostering the viewers of 
the previous events had been successful. "Matilda" was chosen as the champion book. The 25 viewers were there due to the teacher of the English Acting Society letting them know about the event beforehand.

In recent years, extensive reading of English books is also an educational trend in Japan. Bibliobattle of English books will hopefully go along with this trend and create opportunities to read English books, which are often thought to be difficult. There are actually students who started reading English books to participate in this event. Although we started from a small group, we are planning to continue this activity and spread the enjoyment steadily. I think it is worth spreading it inside the school and also around the country. Students have proved to themselves that admiration can become reality in time.

\section{Bibliobattle gathering with other schools}

At Shibuya Junior \& Senior High School, Bibliobattle gatherings with other schools lead

by the library committee have been held since the academic year of 2014, 3 times a year (summer, winter, and spring) before long vacations.

Gathering of 3 high schools (Shibuya, Toshimagaoka, and Shibuyamakuhari)

It is held at our school with 2 schools invited. 3 groups of around 6 participants are formed with 2 students from each school. Viewers who do not give presentations may join the groups. Preliminaries are done within each group and the champion book of each group is chosen. Then, 3 participants give presentations in front of all attendees to decide the grand champion book at the finals.

Gathering of 3 junior high schools (Ohyu, Shiba, and Shibuya)

It is held at Ohyu Gakuen with 3 schools: girls' school Ouyu Gakuen, boys' school Shiba, and coeducational school Shibuya. Everyone is looking forward to the gathering every year since it is interesting with different characteristics of each school and types of books for girls' school, boys' school, and coeducational school.

Gathering of 5 schools (Shibuyamakuhari, Shibuya, Toshimagaoka, Ichikawa, and Hiroo)

This is a big gathering of 5 schools at Shibuyamakuhari. High schools and junior high schools form mixed groups of different years, intentionally not telling their years to create an environment for presentation without constraint. The champion book of last year was "Quiet, please: dispatches from a public librarian" by Scott Douglas, and this year was "Matin Brun" by Franck Pavloff. 
A Schedule Proposal (Sample)

Lead by \#\#\# Library Committee

\#\#, \#\#, and \#\#, 3 high school Bibliobattle gathering plan

Date: \#\#/\#\#/20\#\#

Venue: library of \#\# high school

Students: around 10 students from each school (6 participants of Bibliobattle from each school)

Supervising teachers: \#\# (\#\#), \#\# (\#\#)

Time Table:

13:30-14:00 Arrival of each school, a tour of the library by the Library Committee

14:00-14:10 Self-introduction and grouping (5, 6 members per group)

14:10-15:00 Bibliobattle (5-minute presentation and 2-minute question-and-answer session per member)

15:05-15:30 Bibliobattle finals of champion books from each group

15:30-16:00 a friendly get-together

16:00-16:15 General assessment, photograph session, and breakup

The friendly get-together after the battle is the most enjoyable part for the participants. It can be said that it is the most important part of Bibliobattle. Since it is after introducing books they like in their presentations, it becomes a relaxed gathering with snacks in no time without mental boundaries despite meeting for the first time. They get to know each other better through talking about the books they have introduced and lives at their schools. It is a rich time consisting of tension and flutter of presentations in the first part and the relaxed time afterwards. In the end, in a fond farewell, they may take a commemorative photo posing in a popular anime style in a burst of laughter. One student said, "I think this peaceful and constructive atmosphere will be needed everywhere in the years ahead." This clearly describes the impression of this gathering.

\section{Used Book Fair connecting with the world}

At Shibuya school festival, we receive book donations from students and their family and the used book fair is held with students as the sales staff in the library. All profits are donated to UNESCO. Every year, the students decide which country to support, and for the year of 2015, we have donated to Nepal as they have suffered from recent earthquakes. We care about connecting to the children around the world as well as recycling books and aim for Education for Sustainable Development (ESD).

It was led by the Library Committee at the cultural festival every September and the profits are donated to World Terakoya Movement" * and UNESCO Association Scholarship for 3.11 Disaster Stricken Children and Students to help those children in the disaster areas by 
Northeast Japan Earthquake from 2011 by National Federation of UNESCO Associations in Japan (NFUAJ).

* In 1989, one year before the World Conference on Education for All (EFA) in Jomtien, Thailand, the NFUAJ launched the "World TERAKOYA Movement (WTM)", an international cooperation program for non-formal education. The core objective of the WTM is to provide adult illiterates and out-of-school children with opportunities to learn literacy and places of learning (TERAKOYA = CLC: Community Learning Center), in cooperation with governmental, non-governmental, local and international organizations in partner states.

(http://www.unesco.or.jp/en/activities.html)

The way it is held is, calling for used books from students and guardians through the Library Newsletter from 3 months in advance around June, collecting around 3,000 books every year until the day, students of the Library Committee grouping the books in genres (children's books, comics, general books, English books, etc.) transforming the library like a book shop by the cultural festival, and selling any book for 100yen (around a dollar) as shop staff. In recent years, it is a popular event selling more than 2,000 books in 2 days every year.

The Library Committee thinks of new ways to sell every year, such as preparing with care so that it is easy to look for books by arranging them in alphabetical order by the names of authors and sales have been increasing each year. Thinking of new ways to increase sales, putting it into practice, and seeing the effect become accumulation of imaginative work. The fact that this action is supporting to improve literacy in countries around the world and children's scholarships creates a sense of fulfilment of taking part in contributing to society. The country to donate is chosen through a discussion between the Library Committee and the Volunteering Club. In the recent few years, it was Afghanistan where the literacy rate of girls was said to be low due to factors such as the dispute and last year was Nepal which suffered from an earthquake. Our school is a member of UNESCO Associated Schools. Ministry of Education, Culture, Sports, Science and Technology (MEXT) and The Japanese National Commission for UNESCO place UNESCO Associated Schools as a base for Education for Sustainable Development (ESD) promotion.

\section{Four Basic Fields of UNESCO Associated Schools}

1. Understanding of UN systems to address global issue such as such as poverty, starvation, unemployment, literacy, cultural understanding, gender inequality, population issue or other global problems.

2. Understanding and promotion of human rights and democracy

3. Cross-cultural understanding 
As part of ESD activity, this used book market has been a good opportunity to contribute for a better society through thinking about children's present state around the world and not only Japan as well as environmental problems at the same time through recycling books. Recently, we have heard good news from NFUAJ that a Community Learning Center has been established in Afghanistan. As one of the contributing organizations, the name of Shibuya Junior \& Senior High School is mentioned at the entrance of the CLC.

\section{Conclusion}

These activities have connected students of different age inside or outside the school, who usually do not have interactions, so that they give a great experience for learning about the communication with young children, the same generation, and older people outside the school, who are also rare to interact with. They get self-confidence to live through enjoying the various fruitful interactions.

\section{References}

Akagi, Kanko (2001) Nee Konohon Yonde! (Hey, read this book!) Riburio Publication

Bibliobattle Committee ed (2015) Bibliobattle Handbook, Kodomono Miraisha

Bibliobattle Committee, Culture of Printed Words Promotion Conference (2014) Bibliobattle Symposium 2014 Poster Presentation Abstracts, http://sympo14.bibliobattle.jp/puroguramu/interactive-session

Bibliobattle Official Site: http://en.bibliobattle.jp

Donovan, J., (2013) How to Deliver a TED Talk, Translated by Nakanishi, M., Shinchosha

liyoshi, A. et al. ed. (2014) Education for Sustainable Development, Heibonsha

Japan School Library Association ed., (2009) Chicago Boston New York ni Miru

Tankyugakusyu wo Sasaeru Gakko Toshokan (School Library to Support the Inquiry Learning to See in Chicago, Boston and New York) Japan School Library Association

Kaye, Sharon M. and Paul Thomson (2012) Philosophy for Teens. Trans. Tetsuya Kono Tamagawa University Press

Kobayashi, Kou (1996) Gakko Toshokan Series 3 Tanoshii Yomikikase Kaiteiban (School Library series, Introduction 3: Fun Storytelling Revised Version) Riburio Publication 
Kobayashi, M. (2014) UNESCO Associated Schools Project Network, Akashishoten

Koga, Setsuko (2002) Gakko Keiei to Gakko Tosyokan (School Management and the School Library) Jusonbo

Kono, Tetsuya (2014) "Kodomo Tetsugaku" de Taiwaryoku to Shikoryoku wo Sodateru (Foster a Dialogue Force and Thinking Skills in the "Children's Philosophy") Kawade Shobo Shinsha

Kono, Tetsuya, et al. (2015) Kodomo no Tetsugaku - Kangaerukoto wo Hajimeta Kimie (Philosophy of Child-To You Began to Think) Mainichi Shimbun

McGonigal, J (2011) Reality Is Broken: Why Games Make Us Better and How They Can Change the World, Penguin Books

Revnolds, G., (2012) Simple Presentation, Nikkei BP

Ripman, Mattew, et al. (2015) Philosophy in the Classroom. Trans. Tetsuya Kono and Shogo Shimizu, Kawade Shobo Shinsha

Taniguchi, T (2013) Bibliobattle, Bungeishunju

Taniguchi, T., Kasuya, R., Shimotsuki, M (2014) Let's Enjoy Bibliobattle, Saela Publishing

Taniguchi, T., Kawakami, H., Katai, O. (2010) Bibliobattle: an informal social interaction design mediated by book reviews, The Transactions of Human Interface Society 12(4), 427-437, 2010-11-25

\section{Biographical note}

Yoko TAKAJI has worked as a teacher librarian for Toshimagaoka Joshi Gakuen Junior \& Senior High School since 1993 and a member of book selection committee in Japan School Library Association

Yuki MAEDA has worked for several school libraries, a public library and a children's hall for child welfare in Tokyo, currently a teacher librarian in Shibuya Junior \& Senior High School, a member of book selection committee in Japan School Library Association and a member of Japan Association for the Study of Child Literature 